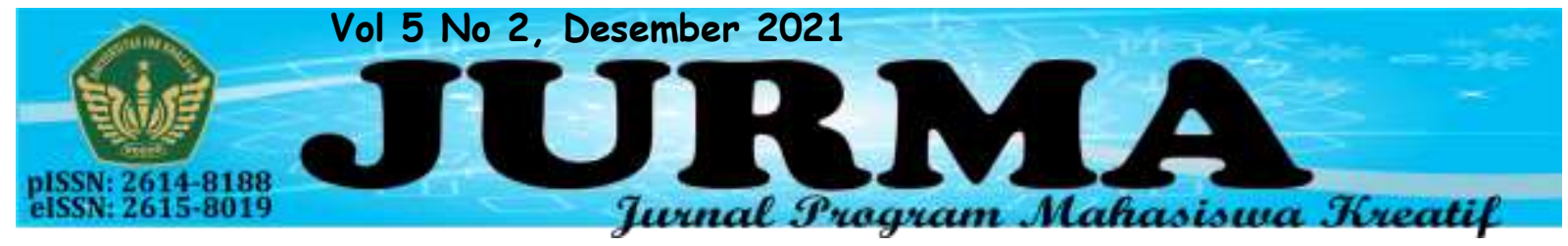

\title{
ANALISIS PENGARUH GADGET TERHADAP MINAT ANAK-ANAK DALAM BELAJAR ALQURAN DI LINGKUNGAN 13, KELURAHAN RENGAS PULAU, KECAMATAN MEDAN MARELAN
}

\author{
Safira Ramadhani ${ }^{1)}$, Ayu Septianty ${ }^{2)}$, Ninda Azzahra ${ }^{3)}$, Fachrur Rozi Nasution ${ }^{4)}$, \\ Annio Indah Lestari ${ }^{5}$ \\ Universitas Islam Negeri Sumatera Utara, Medan \\ safiradhani22@gmail.com ${ }^{1)^{*}}$ ayu.septianty33@gmail.com ${ }^{2)}$ rozie0239@gmail.com ${ }^{3)}$ \\ zahraaninda13@gmail.com $^{3)}$ annionst@gmail.com $^{4)}$
}

\begin{abstract}
ABSTRAK
Perkembangan teknologi yang sudah semakin canggih yang dapat memudahkan kehidupan sehari-hari. Salah satunya yang semakin berkembang saat ini adalah media elekronik, Media yang sangat berpengaruh pada masa sekarang ini adalah Gadget, Gadget merupakan alat komunikasi yang sangat membantu sebagai sarana informasi. Pengaruhnya gadget dapat menurunkannya minat anak dalam belajar Alquran dan banyaknya pengaruh negatif yang terjadi pada perkembangan anak. Pedoman dan petunjuk bagi orang-orang yang beriman ialah Al-quran dan hadis. Meningkatnya pengaruh gadget dapat mempegaruhi perkembangan anak-anak dan terjadinya penurunan minat belajar Alquran terhadap anakanak. Maka tujuan dari penelitian ini untuk mengetahui besarnya pengaruh dari gadget terhadap minat belajar anak dalam membaca Alquran di lingkungan 13, Kelurahan Rengas Pulau, Kecamatan Medan Marelan.
\end{abstract}

\section{Kata Kunci : Pengaruh Gadget, Minat Anak Dalam Belajar Alquran}

\section{ABSTRACT}

The development of increasingly sophisticated technology that can facilitate everyday life. One of them that is growing at this time is electronic media. Media that is very influential at this time is the Gadget, Gadget is a communication tool that is very helpful as a means of information. The influence of gadgets can reduce children's interest in learning the Koran and the many negative effects that occur on children's development. Guidance and guidance for those who believe is the Qur'an and hadith. The increasing influence of gadgets can affect children's development and a decrease in interest in learning the Koran for children. So the purpose of this study was to determine the magnitude of the influence of gadgets on children's learning interest in reading the Koran in 13, Rengas Pulau Village, Medan Marelan District.

\section{Keywords: Effect of Gadgets, Interest in Learning the Qur'an on Children}

\section{PENDAHULUAN}

Gadget adalah sebuah alat mekanis yang terus mengalami pembaruan (upgrade) selain untuk membantu dan memudahkan kegiatan manusia, gadget juga menjadi gaya hidup masyarakat modern saat sekarang ini. Salah satu Gadget yang hampir setiap orang miliki dan senantiasa dibawa pada kehidupan sehari-hari adalah Handphone. Pada Penggunaan Gadget sebagai kekuatan yang timbul dari seseorang dalam menggunakan serta memanfaatkan media gadget yang menunjang dan memenuhi aktivitas kesehariannya 
agar lebih fleksibel, efesien, dan berkualitas.maka dari itu Gadget dianggap sebagai suatu perangkat elekronik yang memilki fungsi khusus pada setiap perangkatnya. Oleh karena itu, Kehadiran Gadget yang awalnya sebagai untuk kepentingan bisnis, perlahan mulai bergeser ke arah gaya hidup. Dengan hal itu, terbukti dengan adanya fitur-fitur hiburan seperti memutar file multimedia (audio/video), internet, BBM, Facebook, Whatsapp dan Line. Menurut Rina Fiati dalam buku Akses Internet Via Ponsel, ponsel sangat bervariasi tergantung pada modelnya, yang seiring dengan perkembangan teknologi mempunyai fungsi-fungsi antara lain: Penyimpanan informasi, Pembuatan daftar pekerjaan atau perencanaan kerja, Alat perhitungan (kalkulator), Pengiriman atau penerimaan e-mail, Permainan (games), Integrasi ke peralatan lain seperti PDA, MP3, Chatingan Browsing internet dan Video (Rina Fiati, 2015).

Anak merupakan anugerah Allah yang terbesar yang diberikan kepada orang tua. Disamping sebagai anugerah, anak merupakan amanat yang dibebankan ke pundak orang tua Allah berfirman:

"Sesungguhnya hartamu dan
anak-anakmu hanyalah cobaan
(bagimu)..."

(QS. At-Taghabun:15)

Amanat yang telah diberikan oleh Allah kepada kedua orang tua harus dijaga dengan penuh keikhlasan dan penuh rasa tanggung jawab, sehingga orang tua dapat menjaga amanat yang telah dibebankan kepadanya. karena bagi seorang muslim harus bisa bersikap amanah dalam memikul tanggung jawab. Anak sebagai makhluk individu dan sosial berhak untuk mendapatkan pendidikan yang sesuai dengan kebutuhan dan kemampuannya. Pendidikan diberikan kepada seorang anak dengan harapan anak dapat tumbuh dan berkembang secara cerdas sesuai dengan potensi yang dimilikinya, supaya kelak dapat menjadi anak bangsa yang berkualitas (Suyadi, 2011). Kebiasaan mempunyai peranan penting dalam kehidupan manusia, karena ia menghemat banyak sekali kekuatan manusia. Kebiasaan yang sudah melekat dan spontan dapat dipergunakan dalam kegiatan-kegiatan produktif seperti bekerja, memproduksi dan mencipta. Bila pembawaan seperti itu tidak diberikan Tuhan kepada manusia, maka tentu mereka akan menghabiskan hidup mereka hanya untuk belajar berjalan, berbicara, dan berhitung (Nur Uhbiyati, 2002).

Alquran merupakan kitab suci yang dijadikan sebagai pegangan hidup umat islam sedunia yang diturunkan kepada Nabi Muhammad saw untuk seluruh umat manusia. Alquran mengajarkan kepada manusia tentang akidah dan tauhid. Kemudian Alquran juga mengajarkan manusia cara beribadah kepada Allah untuk membersihkan qalbu sekaligus menunjukkan kepada manusia mana kebaikan dan keburukkan dalam kehidupan pribadi dan kemasyarakatan. Alquran dapat dibaca, diamalkan, dan dihafal yang semuanya terdapat pahala ketika kita cinta terhadap Alquran. Belajar merupakan cara seseorang untuk mendapatkan berprestasi, agar mampu melakukan sesuatu. Ahmadi, memberikan penjelasan lebih luas dengan mengatakan bahwa minat berarti kecenderungan seseorang untuk memilih atau menolak suatu keinginan, sebenarnya yang dicari bukan kegiatan saja tetapi orang, benda maupun situasi dengan pengertian yang lebih luas. Belajar sesuatu bagi sang anak hanyalah 
sebuah titik tolak. Ketika anak telah memahami makna dari sebuah latihan, maka dia mulai suka untuk mengulanginya kembali, dan anak mengulanginya hingga berkali-kali, dengan kepuasan yang terlihat jelas. Anak senang melakukan aksi tersebut karena dengan aksi tersebut, dia mengembangkan aktivitas-aktivitas psikisnya (Maria Montessori, 2013). Minat secara terminologi adalah sikap jiwa seseorang termasuk ketiga fungsi jiwanya (kognisi, konasi, emosi) yang tertuju pada sesuatu dalam hubungan fungsi jiwa ada unsur perasan yang terkuat. Kemudian minat tidak hanya diekspresikan melalui pernyataan yang menunjukkan bahwa anak lebih menyukai sesuatu dari pada yang lainnya, tetapi juga diimplementasikan melalui partisipasi aktif dalam suatu kegiatan. Anak yang berminat terhadap sesuatu cenderung untuk memberikan perhatian yang lebih besar terhadap sesuatu yang diminati itu dan sama sekali tidak menghiraukan sesuatu yang lain (Abu Ahmadi, 1991).

Dengan belajar membaca Alquran akan menambah minat seseorang untuk mengamalkan Alquran dan menghafalnya. Membaca sebagai aktivitas yang sangat dianjurkan bagi semua umat islam. Hal ini disebabkan oleh besarnya manfaat yang dapat dipetik dari kegiatan dan akan menambah minat anak dalam belajar Alquran (Muhammad Makhdlori, 2007). Maka Al-Qur'an al-Karim sebagai petunjuk dan rahmat bagi orang-orang yang beriman. Orang yang berpegang teguh padanya, baik dengan membaca, menghafal, maupun menerapkan hukum-hukumnya dan menjadikannya sebagai pegangan hidupnya, maka Allah akan memberinya petunjuk dari kesesatan hidup di dunia dan Alquran akan memberinya syaf'at yang dapat melindunginya dari azab pada hari kiamat. Alquran dapat mengajak, memotivasi, dan menuntun setiap orang secara general dan kaum Muslimin secara spesifik agar menyempatkan diri untuk melakukan tadabbur, terlebih dengan diniatkan untuk mendapatkan hikmah agung dari diturunkannya Alquran. (Abu Aisyah Rahendra Maya, 2017).

Ada Manfaat dalam penggunaan Gadget untuk menciptakan suatu masyarakat yang lebih informed yang dapat membuat respon manusia terhadap peristiwa, meningkatnya multi tugas, harga lebih murah, dan memperbesar spesialisasi dalam pekerjaan. Dengan adanya teknologi baru yang lebih canggih seperti sekarang ini, manusia dapat memanfaatkan waktu dan tempat seefesien mungkin dalam menjalankan aktivitasnya (Alo Liliweri, 2011). Dengan demikian banyak tujuan seseorang dalam menggunakan Gadget seperti sebagai sarana untuk memudahkan komunikasi jarak jauh dengan orang lain, baik antar kota ataupun mancanegara, dan juga sebagai media informasi. Gadget membantu komunikasi antar individu dan bahkan antar kelompok dengan berbagai fasilitas layanan yang disediakan oleh jasa telekomunikasi. Keberadaan Gadget kini sudah sangat mengalahkan telephone kabel. Teknologi seluler selalu berkembang terus dan tidak pernah akan berhenti disatu titik. Teknologi berkaitan erat dengan desain dan kualitas suatu produk sehingga masyarakat tidak akan jenuh dengan teknologi yang semakin canggih. Kemudian tujuan lain dari Gadget untuk meningkatkan mutu pembelajaran, efektivitas, serta efesien. Maka banyak Penggunaan gadget yang dapat menimbulkan dampak negatif pada anak usia dini antara lain dengan konten yang kurang baik, mempengaruhi kesehatan fisik (masalah penglihatan, kekakuan, 
cedera tulang belakang karena posisi duduk), mengalami ketergantungan bahkan menghambat perkembangan sosial anak. Dampak dari pengaruh gadget memberikan dampak negatif terhadap interaksi sosial anak. Adapun dampak negatif yang dirasakan oleh anak yaitu dapat mempengaruhi pergaulan sosial anak terhadap lingkungan terdekatnya. Kemudian dalam perkembangan mental anak yang menjadi kurang baik, anak akan menjadi agresif, dan komunikasi anak dengan orangtua ataupun orang lain akan memburuk. Saat sekarang ini banyak anak- anak yang sudah ketergantungan dengan gadget, memiliki sedikit kesempatan dalam berinteraksi dengan orang lain. Seharusnya penggunaan gadget dikembalikan pada fungsi awal, yaitu untuk komunikasi sekaligus sebagai sarana belajar yang menambah ilmu pengetahuan dan anak dituntun untuk lebih kreatif. Dengan adanya media visual dan audio maka anak-anak bisa berimajinasi dan biasanya lebih tertarik. Seperti kegiatan anak browsing buku bacaan yang diinginkan agar nantinya anak-anak dapat mengetahui banyak tentang buku bacaan yang ada sehingga menambah wawasan pada anak dan itu bisa menarik minat baca anak-anak. Namun kebanyakkan zaman sekarang gadget digunakan dalam hal yang tidak berfaedah seperti main game online dan konten yang tidak baik sehingga mengurangi minat anak dalam belajar Alquran.

Dari sinilah, Peran orangtua terhadap anak-anaknya harus selalu dilakukan. Jangan ada sampai orangtua yang mengandalkan gadget untuk menemani aktivitas anaknya. Dan kebanyakan orangtua membiarkan anaknya lebih mementingkan gadget agar tidak menganggu aktivitas orang tuanya. Seharusnya orang tua dapat mengontrol setiap konten yang ada di gadget anak agar anak tersebut tidak menyalahgunakan fungsi gadget dan manfaat dari gadget itu sendiri, dengan mengontrol anak saat bermain gadget merupakan salah satu cara yang efektif agar anak tidak memutar konten yang tidak sewajarnya. Dengan lebih seringnya orang tua mengajak anak untuk berdiskusi, tanya jawab dalam waktu luang akan lebih ke hal positif untuk perkembangan seorang anak. Kemudian bermain bersama atau hanya sekedar bercanda disela-sela aktivitas yang padat akan membuat anak mempunyai banyak waktu dengan orang tuanya. Oleh karena itu, Orang tua merupakan pendidik utama dan ibu sebagai madrasah pertama bagi anak, baik itu dalam lingkungan keluarga yang dikategorikan sebagai institusi pendidikan informal. Sehingga orangtua memiliki kewajiban dan peran mulia dalam meningkatkan minat belajar anak, termasuk minat baca Alquran dalam keluarga (Rahendra Maya, 2013).

Oleh karena itu, setiap orangtua harus memerlukan cara agar anak gemar dan senang dalam membaca Alquran. Untuk mencapai keinginan tersebut maka orangtua harus memperhatikan kegiatan setiap anak dan mempunyai cara tersendiri untuk meningkatkan minat seorang anak dalam belajar Alquran. Hal yang pertama jangan memaksa anak dalam mendidik, Karena minat untuk belajar membaca Alquran muncul dari dalam diri mereka sendiri. Jadi, cukup memberikan stimulasi agar mereka tertarik untuk belajar karena anak adalah pembelajar yang hebat. Lalu orang tua bisa memberikan contoh yang baik, itu adalah cara paling jitu, karena anak adalah peniru yang paling hebat. Dengan menunjukkan kebiasaan dan kebutuhan orangtua dalam belajar membaca Alquran. maka anak akan meniru kebiasaan dari 
orang tuanya, Selanjutnya harus memberikan penjelasan kenapa seorang anak butuh belajar membaca Alquran serta melakukan ibadahibadah lain. Dengan melakukan komunikasi dua arah dengan anakanak akan dapat dimengerti oleh anak kenapa harus belajar Alquran. Dengan penjelasan dari orangtua maka anak akan tahu mengenai kebutuhan

\section{METODOLOGI PENELITIAN}

Konsep penelitian ini dilakukan dengan observasi ke sebuah tempat yang dimana anak- anaknya sudah menggunakan gadget, Penelitian ini mengambil lokasi di lingkungan 13, Kelurahan Rengas Pulau, kecamatan Medan Marelan. Bentuk dalam penelitian ini adalah pendekatan kualitatif. Penelitian kualitatif dapat disebut sebagai serangkaian kegiatan atau proses menjaring data atau informasi yang bersifat sewajarnya (natural) mengenai suatu masalah dalam aspek tertentu dan dari objek tertentu pula.

Metode pengumpulan data merupakan salah satu aspek yang berperan dalam kelancaran dan keberhasilan dalam suatu penelitian. Bogdan Taylor mendefinisikan metode kualitatif adalah metode deskriptif kualitatif. Metode tersebut sebagai prosedur penelitian yang menghasilkan data deskriptif berupa kata tertulis atau lisan dari orangorang dan perilaku yang dapat diamati. Metode ini digunakan karena beberapa pertimbangan. Yakni pertama, menyesuaikan metode deskriptif kualitatif lebih mudah apabila berhadapan dengan kenyataan ganda. Kedua, metode ini menyajikan langsung hakikat hubungan antara peneliti dengan informan. Sumber data adalah subjek dari mana data dapat diperoleh. Dalam hal ini sumber data yang diperoleh dari penelitian diambil dari data primer. beribadah yang menjadi dasar kecintaan anak pada Alquran. Dengan banyaknya anak-anak yang sudah menggunakan gadget sehingga berpengaruh besar terhadap minat anak-anak dalam belajar Alquran maka peniliti mengambil inisiatif untuk melakukan sebuah penelitian di lingkungan 13, Kelurahan Rengas Pulau, Kecamatan Medan Marelan.

\section{Data Primer}

Data primer adalah data yang langsung diperoleh dari sumber data pertama di lokasi penelitian atau objek penelitian. Sebagai data primer dalam penelitian ini adalah masyarakat seprti orang tua dari setiap anak untuk memperoleh data yang valid, maka penulis menggunakan teknik pengumpulan data sebagai berikut :

1) Metode Observasi

Observasi adalah adanya perilaku yang tampak dan adanya tujuan yang ingin dicapai. Maka dari itu, penulis melakukan observasi dan pengamatan secara langsung di lingkungan 13.

2) Angket atau Kuesioner

Angket atau kuesioner adalah teknik pengumpulan data melalui formulir- formulir yang berisi pertanyaan-pertanyaan yang diajukan secara tertulis pada seseorang atau sekumpulan orang untuk mendapatkan jawaban atau tanggapan dan informasi yang diperlukan oleh peneliti. Penelitian ini menggunakan angket atau kuesioer, daftar pertanyaannya dibuat secara berstruktur denan bentuk pertanyaan pilihan berganda (multiple choice questions) dan pertanyaan terbuka (open question). Metode ini digunakan untuk memperoleh data tentang persepsi desain interior dari responden.

3) Studi Pustaka

Studi Pustaka Studi pustaka merupakan langkah awal dalam metode pengumpulan data. Studi 
pustaka merupakan metode pengumpulan data yang diarahkan kepada pencarian data dan informasi melalui dokumen-dokumen, baik dokumen tertulis, foto-foto, gambar, maupun dokumen elektronik yang dapat mendukung dalam proses penulisan.'Hasil penelitian juga akan semakin kredibel apabila didukung foto-foto atau karya tulis akademik dan seni yang telah ada. Studi pustaka merupakan Maka dapat dikatakan bahwa studi pustaka dapat memengaruhi kredibilitas hasil penelitian yang dilakukan.

4) Metode Dokumentasi

Dokumentasi, berasal dari kata dokumen yang artinya barang-barang tertulis. Melalui metode dokumentasi, peneliti gunakan untuk menggali data berupa dokumen terkait pembelajaran daring dan narasumber yang di wawancara.

Uji keabsahan data atau bisa dikatakan sebagai uji validitas atau realibilitas data hasil penelitian kualitatif dapat dilakukan dengan beberapa cara yaitu :

a. Perpanjangan pengamatan, berarti peneliti kembali ke lapangan, melakukan pengamatan, wawancara lagi dengan sumber data untuk kemudian dilakukan cek data.

b. Meningkatkan ketekunan yaitu dengan melakukan pengamatan secara lebih cermat dan berkesinambungan. Dengan cara tersebut maka kepastian data dan urutan peristiwa akan direkam secara pasti dan sistematis.

c. Menggunakan bahan referensi yaitu dengan menggunakan data pendukung untuk membuktikan data yang telah ditemukan oleh peneliti. Seperti hasil wawancara perlu adanya rekaman gambar berupa foto.

d. Mengadakan membercheck yaitu dengan proses pengecekan data yang diperoleh peneliti kepada pemberi data. Tujuannya untuk mengetahui seberapa jauh data yang diperoleh sesuai dengan apa yang diberikan oleh pemberi data.

Analisis data yang digunakan dalam metode penelitian ini adalah deskriftif analitik yang menurut Soegiyono ialah metode yang mendeskripsikan atau yang memberikan gambaran terhadap suatu objek penelitian yang diteliti melalui sampel atau data yang telah terkumpul dan membuat kesimpulan yang berlaku umum. Atau mendeskripsikan data yang dikumpulkan berupa katakata, gambar, dan bukan angka, data yang berasal dari naskah, wawancara, dokumen dan sebagainya, kemudian dideskripsikan sehingga dapat memberikan kejelasan.

\section{HASIL DAN PEMBAHASAN}

Berdasarkan dari hasil kuesioner yang telah dibagikan kepada 37 responden, banyak tanggapan pengaruh gadget terhadap aktivitas anak-anak sudah terpengaruhi mulai dari minat belajar anak dalam membaca alquran maupun minat belajar anak dalam pendidikan. Berikut grafik pangaruhnya gadget terhadap minat anak-anak dalam belajar Alquran : 


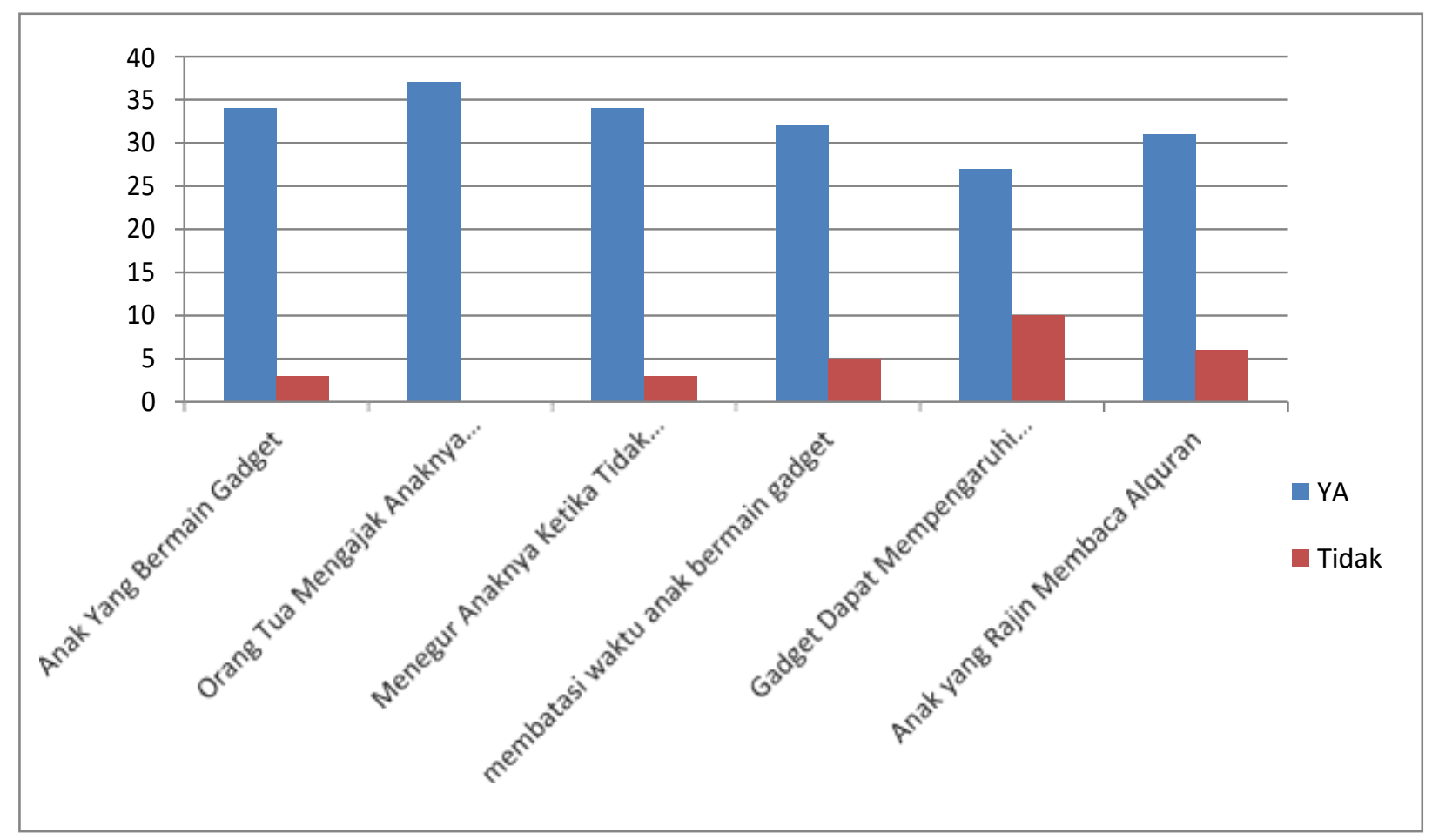

Gambar 1. Grafik pengaruh gadget terhadap minat anak-anak dalam belajar Alquran

Pengaruh gadget bisa terjadi diusia berapa pun baik itu usia muda dan usia tua. Zaman yang sudah mulai canggih saat ini gadget sangat diperlukan dalam hal komunikasi dan lainnya. Banyak diusia muda dan bahkan usia yang masih dini sudah menggunakan gadget tanpa batas sehingga terpengaruhinya gadget terhadap anak-anak lebih besar. Hasil observasi di lingkungan 13, kelurahan rengas pulau, kecamatan medan marelan banyak anak-anak yang sudah menggunakan gadget dan bermain gadget tanpa batas waktu sehingga peneliti melakukan sebuah penelitian yang mengenai pengaruh gadget terhadap minat anak-anak dalam belajar Alquran. Dapat dilihat dari grafik yang ada diatas anak yang bermain gadget lebih banyak dibandingkan anak yang tidak bermain gadget, seluruh orang tua pastinya akan menyuruh atau mengajak anaknya untuk membaca Alquran tetapi ada sebagian anak yang mau diajak ada sebagian anak yang tidak mau dikarenakan kecanduan dalam bermain gadgetnya. Banyak orang tua yang menegur anaknya ketika seorang anak tidak mau membaca Alquran, ada orang tua yang menegur anaknya dengan menasehati kemudian ada juga orang tua yang menegur anaknya dengan memarah karena tidak mau membaca Alquran. Kebanyakkan orang tua pasti membatasi anaknya untuk bermain gadget yang berlebihan dikarenakan dapat merusak mata kemudian dapat bermalas-malasan sehingga aktivitas keseharian seorang anak terganggu. Dari banyak orang tua yang mengisi kuesioner bahwa pengaruh dari gadget akan dapat mempengaruhi perkembangan keagamaan anak, seorang anak dapat tumbuh kembang dengan hal positif karena dengan lingkungan bermainnya. Maka dari itu perkembangan anak dalam keagamaan akan dipengaruhi oleh gadget ketika seorang anak itu tidak tau hal buruk dan hal yang baik didapatkan dalam suatu gadget yang dimainkannya. 
Gadget akan membawa perkembangan yang baik ketika memanfaatkan gadget dengan hal yang positif ketika gadget dimanfaatkan untuk hal negatif akan rusak perkembangan anak yang dipengaruhi oleh fitur gadget itu sendiri. Gadget dapat menjadikan anak rajin dalam belajar membaca Alquran karena didalam gadget terdapat aplikasi mushaf Alquran yang bisa dibaca ketika saat santai maupun dalam perjalanan. Dalam lingkungan 13 , kelurahan rengas pulau, kecamatan medan marelan banyak anak- anak yang membaca Alquran tetapi sering juga anak yang candu akan gadget. Media yang sangat berpengaruh pada masa sekarang ini adalah Gadget, karena dengan Gadget dapat digunakan sebagai alat komunikasi, memperoleh informasi, media belajar serta media hiburan. Gadget merupakan alat komunikasi yang sangat membantu sebagai sarana informasi. Kemajuan teknologi yang semakin canggih pada masa sekarang ini membuat gadget dengan berbagai jenis dan fitur yang menarik seperti BBM, Instagram, Facebook, Line, WhatsApp, dan lain-lain. Gadget yang dahulu merupakan barang mewah dan hanya dimiliki oleh orang-orang dengan tingkat ekonomi menengah ke atas, sekarang setiap orang dapat memilikinya sampai pada masyarakat kelas bawah mulai dari anak-anak hingga orang dewasa, hampir di seluruh lapisan masyarakat telah menggunakan Gadget (Dasrun Hidayat, 2012).

Seringnya anak-anak bermain gadget akan berdampak kepada dirinya sendiri seperti minat belajar yang berkurang karena sudah keasikkan dengan gadget yang dimainkan. Adanya anak-anak yang membaca Alquran hanya sekedar membaca tidak mengamalkan atau mempelajari bacaan Alquran tersebut. Kewajiban seorang orang tua juga harus mengingatkan anak-anaknya dalam membaca Alquran minimal sehari sekali. Untuk memperhatikan dan senantiasa mengikuti serta mengawasi anak-anaknya, dalam segi kehidupan dan pendidikan yang universal. Dibawah ini beberapa nash tentang keharusan memperhatikan dan melakukan pengawasan: (Abdullah Nashih Ulwan, 1995).

"Hai orang-orang yang beriman, peliharalah dirimu dan keluargamu dari api neraka yang bahan bakarnya adalah manusia dan batu, penjaganya malaikat-malaikat yang kasar, keras, yang tidak mendurhakai Allah terhadap apa yang diperintahkan-Nya kepada mereka dan selalu mengerjakan apa yang diperintahkan."

(At-Tahrim: 6)

Pentingnya sosok orang tua yang mengingatkan waktu anaknya dalam hal bermain gadget karena gadget bisa berdampak buruk dan bisa juga berdampak baik untuk anak- anak. Banyak dengan dampak gadget tersebut anak-anak malas untuk melakukan aktivitas kesehariannya bahkan minta belajar yang seharusnya meningkat untuk prestasinya dengan adanya gadget menjadi menurun minat belajar anak karena pengaruh yang begitu besar ketika salah penggunaan gadget terhadap anak-anak. Banyak responden yang menjawab bahwa pengaruh malasnya anak untuk membaca Alquran itu dipengaruhi oleh gadget itu sendiri, sehingga dampak yang terjadi minat anak terhadap Alquran dapat berkurang. Mulai dari kecil anak-anak sudah terbiasa mengaji atau membaca Alquran itu setelah magrib, jadi kebanyakan anak-anak yang sudah diteliti dan orang tua juga mengatakan anak-anak setelah magrib adalah suatu kebiasaan sehari- hari yaitu mengaji di 
masjid. Orang tua banyak yang mengatakan bahwa gadgat itu dapat mempengaruhi minat belajarnya seorang anak dalam belajar Alquran. Anak yang sudah candu pada gadget akan malas untuk melakukan aktivitas lainnya. Banyak game online yang sering dimainkan oleh anak-anak sehingga membuat mereka lupa akan waktu. Banyak dari orang tua yang memarahkan anaknya ketika seharian bermain gadget sehingga anak tersebut menjadi ingin lebih untuk melakukan aktivitasnya di gadget. Nashih Ulwan mengatakan tanggung jawab yang paling penting dan diperhatikan oleh Islam adalah tanggung jawab pendidik terhadap anakanak yang berhak menerima pengarahan, pengajaran, dan pendidikan dari mereka (Abdullah Nashih Ulwan, 1995). Seharusnya orang tua menasehati dengan baik sehingga anaknya tau kenapa alasan dilarang bermain gadget dalam seharian. Dengan adanya teknologi baru yang lebih canggih seperti sekarang ini, manusia dapat memanfaatkan waktu dan tempat seefesien mungkin dalam menjalankan aktivitasnya (Alo Liliweri, 2011).

Banyak dampak yang terjadi ketika selalu bermain gadget, dampak yang sering terjadi timbulnya kemalasan kemudian timbulnya kejahatan yang tidak diinginkan dan timbulnya fitur-fitur yang seharusnya belum dilihat oleh anak-anak. Penggunaan gadget yang berlebihan pada anak akan berdampak negatif karena dapat menurunkan daya konsentrasi dan meningkatkan ketergantungan anak untuk dapat mengerjakan berbagai hal yang semestinya dapat mereka lakukan sendiri. Dampak lainnya adalah semakin terbukanya akses internet dalam gadget yang menampilkan segala hal yang semestinya belum waktunya dilihat oleh anak-anak. Banyak anak yang mulai kecanduan gadget dan lupa bersosialisasi dengan lingkungan sekitarnya yang berdampak psikologis terutama krisis percaya diri juga pada perkembangan fisik anak (Hudaya, 2018). Ada juga dampak positif yang terjadi karena pengetahuan yang semakin berkembang dengan gadget dapat menambah wawasan yang ada di gadget, dapatnya memudahkan komunikasi jarak jauh, dan yang terakhir bisanya berbelanja online ataupun belajar online yang memudahkan aktivitas. Banyak orang tua yang meberikan rewards ke anaknya ketika sudah mengkhatamkan Alquran yang sebagai bentuk dukungan orang tua terhadap anak untuk terus meningkatkan minat anak dalam belajar Alquran. Sehingga pengaruh baik dan buruk dari gadget itu ada, hanya saja pengguna gadget akan menggunakan untuk hal positif atau hal yang negatif.

\section{KESIMPULAN DAN SARAN}

Dapat ditarik kesimpulan bahwa tingginya intensitas anak-anak yang sudah mempunyai gadget diusia dini dan seringnya anak-anak yang bermain gadget. Penggunaan gadget di saat sekarang ini semakin meningkat dan pengaruh besar yang terjadi juga akan semakin besar. Pengaruh gadget terhadap minat anak-anak dalam belajar Alquran dapat mempengaruhi anak-anak sehingga terjadi kemalasan dan menurunnya minat belajar anakanak dalam membaca Alquran. Peran orang tua dalam mengontrol dan membimbing anak-anaknya untuk meningkatkan belajar Alquran sangat diperlukan. Dalam minat anak-anak belajar Alquran di lingkungan 13 sudah cukup baik tetapi dengan adanya alat media yang canggih seperti gadget dapat mempengaruhi minat anak-anak dalam belajar Alquran sehingga menurunnya minat belajar dan dapat menganggu aktivitas 
anak dalam penggunaan gadget yang berlebihan.

Adapun saran yang bisa diberikan ialah Penelitian ini memiliki banyak kekurangan terkait dengan pembahasan yang kurang mendalam dalam. Hal ini dikarenakan masih minimnya pengetahuan penulis. Oleh karena itu kritik dan saran yang membangun dari para pembaca sangat penulis harapkan sebagai bahan evaluasi untuk kedepannya.

\section{DAFTAR PUSTAKA}

Ahmadi, Abu. 1991. Psikologi Umum.Jakarta: PT Rineka Cipta.

Hidayat, Dasrun. 2012. Komunikasi Antar Pribadi dan Medianya. Yogyakarta: Graha Ilmu.

Hudaya, A. 2018. Pengaruh gadget terhadap sikap disiplin dan minat belajar peserta didik. Research and Development Journal of Education, 4(2).

Liliweri, Alo. 2011. Komunikasi Serba Ada Serba Makna. Jakarta: Prenada Media Grup

Lintang Lazuardi. Pustaka Pelajar

Makhdlori, Muhammad. 2007. Keajaiban Membaca Al-Qur'an. Yogyakarta: Diva Press Maya,
Abu Aisyah Rahendra. 2017. Perspektif Al-Qur'an Tentang Konsep Al- Tadabbur. AlTadabbur: Jurnal Ilmu AlQur'an dan Tafsir STAI Al Hidayah Bogor. Vol 01 No. 01.

Maya, Rahendra. 2013. Esensi Guru dalam Visi Misi Pendidikan Karakter. Edukasi Islami: Jurnal Pendidikan Islam, STAI AlHidayah Bogor. Vol 03 No. 02

Montessori, Maria. 2013. Gerald Lee Gutex (ed.), Metode Montessori, Terj. Ahmad

Rina Fiati dalam Afif Fatimahtuz Zahro "Hubungan Intensitas Penggunaan Gadget terhadap Kedisiplinan menghafal AlQur'an di Pondok Pesantren Almuntaha Cebongan Salatiga" (Skripsi Sarjana Fakultas Tarbiyah dan Keguruan IAIN Salatiga, Cirebon, 2015), h. 18.

Suyadi. 2011. Manajemen PAUD. Yogyakarta: Pustaka Pelajar.

Uhbiyati, Nur. 2002. Dasar-Dasar Ilmu Pendidikan Islam. Semarang: Pustaka Rizki Putra. Ulwan, Abdullah Nashih. 1995. Pendidikan Anak Dalam Islam. Jakarta: Pustaka Amani 